\title{
Nutritional and Organoleptic Properties of Oat Milk Dessert Enriched with Paneer and Standardized Milk
}

\author{
Akanksha Yadav, Ramesh Chandra', Luxita Sharma²
}

10.18805/ajdfr.DR-1601

\begin{abstract}
Background: Dessert with good nutritional value could play an important role in the physical and mental growth and development of infants, children and teenagers as well as great tasty food choice of adult and ageing. The aim of the present study was to evaluate the nutritional and organoleptic quality of oat milk dessert. Nine types of dessert prepared from an admixture of oat milk and standardized milk having different ratio of $1: 1,1: 2$ and $1: 3$ indicate as $\mathrm{TO}_{1}, \mathrm{TO}_{2}$ and $\mathrm{TO}_{3}$, respectively and three different levels of paneer i.e. $5 \%$ $10 \%$ and $15 \%$ indicated as $P_{1}, P_{2}$ and $P_{3}$ respectively were compared to each other.

Methods: The study was executed in the Research Laboratory of Warner School of Food and Dairy Technology, SHUATS during 2012 - 2013. Dessert prepared from standardized milk with addition of 10 percent paneer which served as $T_{0} P_{2}$ (control). The experiment was replicated three times and the data was statistically analyzed by using analysis of variance ANOVA and critical difference (C.D) techniques. Dessert were determined according to the AOAC methods and their organoleptic acceptability by using 9 point Hedonic Scale.

Result: Nutritional content of oat milk dessert experimental sample $\left(\mathrm{TO}_{3} \mathrm{P}_{3}\right)$ showed that protein $(9.23 \%)$, carbohydrate $(28.55 \%)$, ash $(2.13 \%)$ and fat $(12.96 \%)$. Oat milk dessert gained acceptability in terms of sensory attributes hence was concluded to be a potential nutritious dessert for all vulnerable age group as nutrient-dense food.
\end{abstract}

Key words: Dessert, Oat milk, Orgenoleptic properties, Paneer, Standardized milk.

\section{INTRODUCTION}

With increase in health awareness among the population and oats being prescribed by healthcare professionals like physicians and nutritionists, as an adjunct therapy for various chronic degenerative diseases, the popularity of oats is on rise. Demand of oat-based product has been increased due to increased knowledge about the many nutritional benefits of oats. Thus promoting its use in functional food products based on oat such as oatmeal, granola bars, oat flour, oat milk ice cream, oat bread, biscuits and cookies, oat milk, oat paneer, oat based probiotic drink, oat based breakfast cereals, flakes and infant food. Oats are good source carbohydrates and quality protein with contribution good amino acid balance, vitamins, minerals unsaturated fatty acid and phyto-chemicals (Head et al., 2010). Oats are also rich source of antioxidant compound such as tocopherols, flavonoids and phenolic compounds that may be contributing factors to potential health benefits of the consumers. Oats have been widely shown to provide a vast range of human health benefits such as manage the level of fasting blood sugar and also controlled the weight gain in patients with Gestational Diabetes Mellitus (GDM) (Shahzeidi et al., 2019).

Oat milk is a recommended dairy milk substitute for individuals who suffer from Irritable Bowel Syndrome (IBS) and Inflammatory Bowel Disease (IBD) (Olendzki et al., 2014). The Beta-glucan content present in oat milk was responsible for the decreased plasma cholesterol and LDL cholesterol concentrations, but the effect could also be due to a replacement of saturated fat in the customary diet by unsaturated fat. Therefore, oat milk can be used as an
Department of Nutrition and Dietetics, Faculty of Allied Health Sciences, Shree Guru Gobind Singh Tricentenary University, Gurgaon-122 505, Haryana, India.

'Warner School of Food and Dairy Technology, Sam Higginbottom University of Agriculture, Technology and Sciences, Formerly Allahabad Agricultural Institute, Allahabad, Prayagraj-211 007, Uttar Pradesh, India.

2Department of Dietetics and Applied Nutrition, Amity Medical School Amity University, Gurgaon-122 505, Haryana, India.

Corresponding Author: Akanksha Yadav, Department of Nutrition and Dietetics, Faculty of Allied Health Sciences, Shree Guru Gobind Singh Tricentenary University, Gurgaon-122 505, Haryana, India. Email: akankshayadav5@gmail.com

How to cite this article: Yadav, A., Chandra, R. and Sharma, L. (2021). Nutritional and Organoleptic Properties of Oat Milk Dessert Enriched with Paneer and Standardized Milk. Asian Journal of Dairy and Food Research. 40(2): 167-171. DOI: 10.18805/ajdfr.DR-1601.

Submitted: 11-11-2020 Accepted: 14-04-2021 Online: 30-04-2021

alternative to other milk drinks by consumers who would benefit from reduced the risk of non communicable diseases. Paneer is a fairly high source of protein and available at a comparatively lower cost and also forms an important source for vegetarians. Over and above its high protein content and digestibility, the biological value of protein in paneer is in the range of 80 to 86 (Khan and Pal, 2011).

Milk and dairy products are rich in nutrients like calcium and vitamin $D$ that are required for building strong bones in childhood and for their maintenance during adulthood with the aim to reduce osteoporosis and bone fractures in older 
Nutritional and Organoleptic Properties of Oat Milk Dessert Enriched with Paneer and Standardized Milk

age. Whereas low-fat, calcium-rich dairy products are associated with a lower risk of blood pressure.

Desserts are well known in many cultures of the society as sweet courses that typically come at the end of a meal. They usually comprise of sweet and creamy food and, consequently, high in sugar and saturated fat content (Alija and Talents, 2012). However, as long as changing dietary patterns and sedentary lifestyles have led to an increase in worldwide obesity, as a result, people have come to expect something healthy from their diet in recent decades (SeussBaum, 2007). Thus, largely influenced by health-related concerns, there has been advised on the food industry to reduce the amount of saturated and trans fat, sugar, salt and certain additives in the diet (Alija and Talents, 2012; Nikzade et al., 2012).

The product innovation of oat milk admixture with standardized milk and paneer based, in the form of healthy products, is essential with the aim of producing nutritious dessert. This product then can be used to overcome the problem of nutrition-health, especially for non-communicable diseases. Besides containing calories, nutritious dessert has protein, carbohydrate, total solids, antioxidants, vitamins and minerals, which are important for the human body. However, the development of healthy products from oat milk and paneer, in the form of dessert, is less studied.

\section{Aim of the study}

The aim of the present study was to develop a suitable methodology for the preparation of a dessert and to determine its organoleptic properties with the nutritional composition.

\section{MATERIALS AND METHODS}

\section{Locale of the study}

The study was executed in the Research Laboratory of Warner School of Food and Dairy Technology, SHUATS, Allahabad, UP. Whole milk was procured from the Student's Training Dairy, SHUATS, Allahabad for each replication and other ingredients (Paneer, Sugar and Cardamom), packaging materials were also purchased from the local market of Allahabad and oat was purchased from IARI, Pusa, New Delhi. The different treatment combinations used in the experiment have been listed in Table 1 . The total numbers of trials were 30 in this study.

\section{Method of preparation of oat milk}

Oat milk was prepared according to the enzymatic method. About $1 \mathrm{~kg}$ of rolled oats was ground into a laboratory food processor to produce finely granulated oat flour and then mixed with $2.7 \mathrm{~kg}$ of water. Calcium chloride at a concentration of $0.04 \%(\mathrm{w} / \mathrm{w})$ was added as a catalyst for the enzyme. Oat groat slurry was treated with "-amylase (77.78 $\mathrm{mg} \mathrm{kgG1}$ of rolled oats) for liquefaction for $49 \mathrm{~min}$ at 75EC. The liquefied Oat solids were then filtered through a muslin cloth to get the oat milk. At the end of the treatment, the enzyme was inactivated by heating at $100 \mathrm{EC}$ for $5 \mathrm{~min}$.
Table 1: Details of control and experiment treatment combinations of dessert.

\begin{tabular}{lccc}
\hline Treatments & $\begin{array}{c}\text { Standardized } \\
\text { milk }\end{array}$ & $\begin{array}{c}\text { Oat milk and } \\
\text { standardized milk }\end{array}$ & Paneer \\
\hline $\mathrm{T}_{0} \mathrm{P}_{2}$ & $100 \%$ & - & $10 \%$ \\
$\mathrm{TO}_{1} \mathrm{P}_{1}$ & - & $1: 1$ & $5 \%$ \\
$\mathrm{TO}_{1} \mathrm{P}_{2}$ & - & $1: 1$ & $10 \%$ \\
$\mathrm{TO}_{1} \mathrm{P}_{3}$ & - & $1: 1$ & $15 \%$ \\
$\mathrm{TO}_{2} \mathrm{P}_{1}$ & - & $1: 2$ & $5 \%$ \\
$\mathrm{TO}_{2} \mathrm{P}_{2}$ & - & $1: 2$ & $10 \%$ \\
$\mathrm{TO}_{2} \mathrm{P}_{3}$ & - & $1: 2$ & $15 \%$ \\
$\mathrm{TO}_{3} \mathrm{P}_{1}$ & - & $1: 3$ & $5 \%$ \\
$\mathrm{TO}_{3} \mathrm{P}_{2}$ & - & $1: 3$ & $10 \%$ \\
$\mathrm{TO}_{3} \mathrm{P}_{3}$ & - & $1: 3$ & $15 \%$ \\
\hline
\end{tabular}

Sample code - $\mathrm{T}_{0} \mathrm{P}_{2}$ Served as Control ( Admixtue of standardized milk and paneer) while $\mathrm{TO}_{1} \mathrm{P} 1, \mathrm{TO}_{1} \mathrm{P}_{2}, \mathrm{TO}_{1} \mathrm{P}_{3}, \mathrm{TO}_{2} \mathrm{P}_{1}, \mathrm{O}_{2} \mathrm{P}_{2}, \mathrm{TO}_{2}$ $\mathrm{P}_{3}, \mathrm{TO}_{3} \mathrm{P}_{1}, \mathrm{TO}_{3} \mathrm{P}_{2}$ and $\mathrm{TO}_{3} \mathrm{P}_{3}$ - Served as experiment (Addition of paneer at at different levels with oat and standardized milk at different ratios as given Table 1).



Fig 1: Flow diagram of preparation of oat milk dessert. 
The total yield was $(78 \%)$ estimated as the percentage of the filtrate obtained.

\section{Preparation of oat milk dessert}

Following procedure was used for the preparation oat milk dessert (Fig 1).

\section{Nutritional analysis of oat milk dessert}

Protein and fat were determined according to the procedure described in AOAC (2000). The moisture content of oat milk desserts was determined as per the procedure given in exercise 31 of the Manual in Dairy Chemistry, ICAR (1972). The total Carbohydrate was calculated by the difference method (FAO, 1998; AOAC, 2000). Ash content of oat milk dessert was determined according to the method described in AOAC IS2333: 1997 (1980). The total solid content in the dessert was determined according to the method described in IS: 1479, 1960 (ISI (1968).

\section{Organoleptic properties of dessert}

The products developed were subjected to organoleptic evaluation by a panel of five judges. The evaluation of the product was carried out by using the 9-point Hedonic scale (Srilakshmi, 2007). Organoleptic evaluation of nutritious dessert was done for the color and appearance, consistency, flavor and taste as also for overall acceptability.

\section{Statistical analysis}

All the experiments were carried out in triplicate and represented as mean \pm standard deviation (SD). The data obtained for various parameters were analyzed statistically using Two-way Analysis of Variance (ANOVA) and Critical Difference (C.D.) techniques.

\section{RESULTS AND DISCUSSION}

\section{Proximate composition}

Nutrient analyses of different treatment combinations of samples are presented in (Table 2). It includes the analysis of the sample for moisture, total solids, carbohydrate, protein, fat and ash. The results obtained after the analysis of desserts and conclusions there from are as follows: -

\section{Moisture percentage in oat milk dessert}

The maximum amount of moisture content among the different treatment combinations of oat milk dessert was found in $\mathrm{TO}_{1} \mathrm{P}_{1}(54.73 \%)$ followed by $\mathrm{TO}_{2} \mathrm{P}_{1}(53.35 \%), \mathrm{TO}_{3} \mathrm{P}_{1}$ (52.86\%), TO $\mathrm{P}_{2}(52.13 \%), \mathrm{TO}_{2} \mathrm{P}_{2}(50.56 \%), \mathrm{TO}_{1} \mathrm{P}_{3}$ $(50.34 \%), \mathrm{TO}_{2} \mathrm{P}_{2}(50.22 \%), \mathrm{TO}_{3} \mathrm{P}_{2}(48.55 \%), \mathrm{TO}_{2} \mathrm{P}_{3}$ $(48.47 \%)$ and lowest amount of moisture was recorded in $\mathrm{To}_{3}$ $\mathrm{P}_{3}(47.13 \%)$ (Table 2). Statistical analyses revealed that the moisture content of the treatment combinations was significantly different from each other.

\section{Fat percentage in oat milk dessert}

The highest fat content was recorded in sample $\mathrm{TOP}_{2}$ $(13.43 \%)$ followed by $\mathrm{TO}_{3} \mathrm{P}_{3}(12.96 \%), \mathrm{TO}_{3} \mathrm{P}_{2}(11.54 \%)$, $\mathrm{TO}_{2} \mathrm{P}_{3}(11.32 \%), \mathrm{TO}_{2} \mathrm{P}_{2}(10.49 \%), \mathrm{TO}_{1} \mathrm{P}_{3}(10.33 \%), \mathrm{TO}_{3} \mathrm{P}_{1}$ $(9.57 \%), \mathrm{TO}_{1} \mathrm{P}_{2}(9.35 \%)$ and $\mathrm{TO}_{2} \mathrm{P}_{1}(8.60 \%)$, while the lowest crude fat content was observed in $\mathrm{TO}_{1} \mathrm{P}_{1}(7.64 \%)$. Statistical analysis of the crude fat content revealed that the difference was observed to be significant in most of the treatment combinations. Oat milk can be used as a supplementation of the product as well as who would benefit from reduced LDL cholesterol values (Onning et al., 1998).

\section{Protein percentage in oat milk dessert}

The highest protein content was found in $\mathrm{TOP}_{2}(10.27 \%)$ followed by $\mathrm{TO}_{3} \mathrm{P}_{3}(9.23 \%), \mathrm{TO}_{3} \mathrm{P}_{2}(8.48 \%), \mathrm{TO}_{2} \mathrm{P}_{3}(8.36 \%)$, $\mathrm{TO}_{3} \mathrm{P}_{1}(7.41) \%, \mathrm{TO}_{2} \mathrm{P}_{2}(7.28 \%), \mathrm{TO}_{1} \mathrm{P}_{3}(6.72 \%), \mathrm{TO}_{2} \mathrm{P}_{1}$ $(6.53 \%)$ and $\mathrm{TO}_{1} \mathrm{P}_{2}(6.14 \%)$, whereas least protein content was recorded in $\mathrm{TO}_{1} \mathrm{P}_{1}(5.45 \%)$. Statistical analysis proved that all treatment combinations of oat milk desserts were significantly different from one another.

\section{Carbohydrate percentage in oat milk dessert}

The highest carbohydrate content of oat milk dessert was noted to be $30.68 \%$ in $\mathrm{TO}_{1} \mathrm{P}_{3}$ followed by $\mathrm{TO}_{1} \mathrm{P}_{2}(30.52 \%)$, $\mathrm{TO}_{1} \mathrm{P}_{1}(30.41 \%), \mathrm{TO}_{2} \mathrm{P}_{3}(29.85 \%), \mathrm{TO}_{2} \mathrm{P}_{2}(29.71 \%), \mathrm{TO}_{2} \mathrm{P}_{1}$ $(29.63 \%), \mathrm{TO}_{3} \mathrm{P}_{3}(28.55 \%), \mathrm{TO}_{3} \mathrm{P}_{2}(28.45 \%)$ and $\mathrm{TO}_{3} \mathrm{P}_{1}$ $(28.24 \%)$ while the lowest carbohydrate content was observed in $\mathrm{TOP}_{2}$ (24.30). Statistical analysis indicated that the carbohydrate content differed significantly in most of the treatment combinations.

\section{Total solids percentage in oat milk dessert}

The maximum amount of total solids content among the different treatment combinations of oat milk dessert was found in $\mathrm{TO}_{3} \mathrm{P}_{3}(52.87 \%)$ followed by) by $\mathrm{TO}_{2} \mathrm{P}_{3}(51.53 \%)$, $\mathrm{TO}_{3} \mathrm{P}_{2}(50.45 \%), \mathrm{TOP}_{2}(49.78 \%), \mathrm{TO}_{1} \mathrm{P}_{3}(49.66 \%), \mathrm{TO}_{2} \mathrm{P}_{2}$ (49.44\%), $\mathrm{TO}_{1} \mathrm{P}_{2}(47.87 \%), \mathrm{TO}_{3} \mathrm{P}_{1}(47.14 \%), \mathrm{TO}_{2} \mathrm{P}_{1}(46.65 \%)^{2}$ and lowest content of total solids was recorded in $\mathrm{TO}_{1} \mathrm{P}_{1}$ (45.27\%). Statistical analyses revealed that total solids content of the treatment combinations were significantly different from each other.

\section{Ash percentage in oat milk dessert}

The ash content of the different treatment combinations of oat milk dessert ranged from $2.13-1.77 \%$. The highest ash of 2.13 was recorded in $\mathrm{TO}_{3} \mathrm{P}_{3}$ followed by $\mathrm{TO}_{2} \mathrm{P}_{3}(2.00 \%)$, $\mathrm{TO}_{3} \mathrm{P}_{2}(1.98 \%), \mathrm{TO}_{2} \mathrm{P}_{2}(1.96 \%), \mathrm{TO}_{1} \mathrm{P}_{3}(1.93 \%), \mathrm{TO}_{3} \mathrm{P}_{1}$ (1.92\%), $\mathrm{TO}_{2} \mathrm{P}_{1}(1.89 \%), \mathrm{TO}_{1} \mathrm{P}_{2}(1.86 \%), \mathrm{TOP}_{2}(1.78 \%)$ and lowest content of Ash was recorded in To1P1 (1.77\%). Statistical analyses found that the ash content of the treatment combinations was significantly different from each other.

\section{Organoleptic properties of oat milk dessert}

The organoleptic characteristics of oat milk dessert produced are presented in (Table 3). Desserts were evaluated for color and appearance, consistency, flavor and taste and overall acceptability. (Shivendra et al., 2018) found that sensory evaluation of channa kheer had highly acceptable by consumers.

\section{Color and appearance}

The highest color and appearance score of 8.72 was recorded in $\mathrm{TOP}_{2}$ and the lowest in $\mathrm{TO}_{1} \mathrm{P}_{1}$ (7.15). Due to different ratios of oat milk and standardized milk along with 

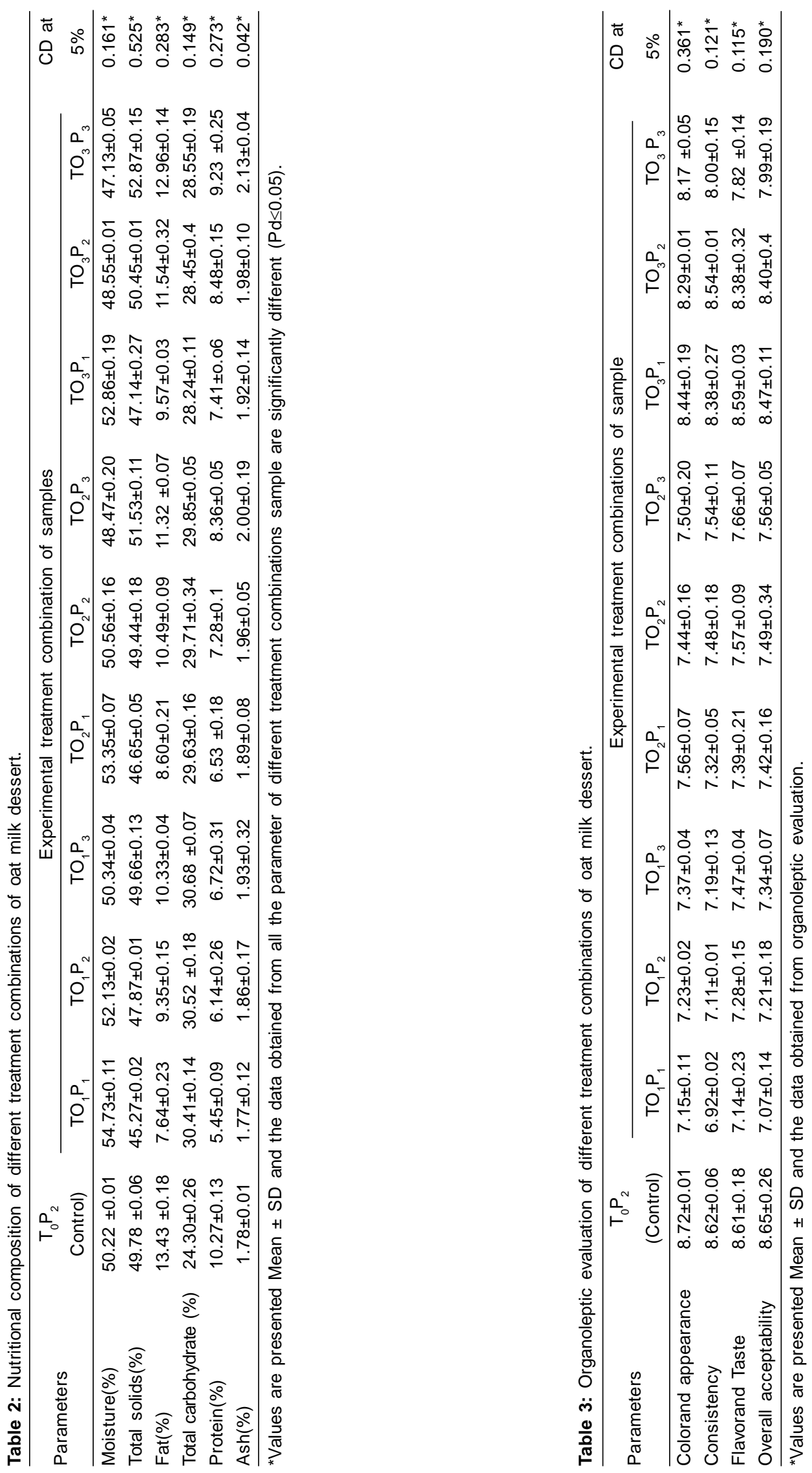
paneer level in different treatment combinations, it was observed that there was a significant difference in the most treatment combinations.

\section{Consistency}

Mean organoleptic mean score for the consistency of different treatment combinations of oat milk dessert ranged from 6.92-7.8.62. The maximum score of 8.62 was found in sample $\mathrm{TOP}_{2}$ and a minimum score of 5.43 observed in sample $\mathrm{TO}_{1} \mathrm{P}_{1}$. The difference was observed to be significant in most of the treatment combinations.

\section{Flavour and taste}

Flavour and taste are important criteria for deciding the quality of the product, which in term determines its acceptability. The sensory score for the flavor and taste of oat milk dessert as affected by different ratios of oat and standardized milk and also different levels of paneer are presented in Table 1. It was observed that the average flavor and taste score was highest in $\mathrm{TOP}_{2}$ (8.61) and lowest in $\mathrm{TO}_{1} \mathrm{P}_{1}$ (7.14). The difference was found to be significant in most of the treatments. (Bakshi et al., 2019) found that the use of milk, bottle gourd and rice powder for milk-based dessert was acceptable in flavor and taste.

\section{Overall acceptability}

The highest overall acceptability score of 8.65 was found in $\mathrm{TOP}_{2}$ as compared to other treatments. Lowest overall acceptability was seen for treatment $\mathrm{TO}_{1} \mathrm{P}_{1}$ (7.07) respectively. The difference was found to be significant in most of the treatment combinations. (Batawy et al., 2019) found that oat milk could be used as good raw material as functional food.

\section{CONCLUSION}

From our study, it can be concluded that the addition of oat milk and paneer enhances the nutritional content and sensory properties of oat milk dessert. The nutritional value of the sample $\left(\mathrm{TO}_{3} \mathrm{P}_{3}\right)$ was found to be rich in carbohydrate, total solids, ash but low in fat, protein and moisture content as compared to sample $\mathrm{TOP}_{2}$ (control). Thus, oat milk dessert can be preferred as a healthy natural food product for all vulnerable age groups as well as under nutrition.

\section{ACKNOWLEDGEMENT}

We acknowledge Sam Higginbottom University of Agriculture, Technology and Sciences, formerly Allahabad Agricultural Institute for supporting and providing Lab and other facilities for the research activity in the Research Laboratory of Warner School of Food and Dairy Technology, (SHUATS,) Allahabad, UP.

\section{Conflict of Interest}

There is no conflict of interest among the authors.

\section{REFERENCES}

Alija, J. and Talents, C. (2012). New concept of desserts with no added sugar. Int. J. Gastron. Food Sci. 1: 116-122.

AOAC (1980). Official Method of Analysis, Assoc. off. Anal. Chem., Washington; D.C. $13^{\text {th }}$.

AOAC. (2000). Official Methods of Analysis of AOAC International, Gaithersburg. MD, USA: Association of Official Analytical Chemists.

Batawy,O,I., Mahdy, S,M. and Gohari.,T,S., (2019). Development of functional fermented oat milk by using probiotic strains and Whey protein. International Journal of Dairy Science. 14(1): 21-28.

Bakshi, P., Yadav, A., Chandra, R. and Yadav, B. (2019). Development of a process to prepare milk based dessert using bottle gourd and rice powder. Asian J. Dairy and Food Res. 38(1): 1-6.

FAO. (1998). Carbohydrates in Human Nutrition. Report of a Joint FAO/WHO Expert Consultation (FAO Food and Nutrition Paper 66) Food and Agriculture Organization. Rome.

Head, DS., Cenkowski, S., Arntfield, S. and Henderson, K. (2010). Superheated steam processing of oat groats. LWT - Food Sci. Technol. 43: 690-694.

Indian Standards: (1479) (Part I) (1960). Method of Testing for Dairy Industry Rapid Examination of Milk. Indian standards Institution. New Delhi. 144-145.

Khan, S.U. and Pal, M.A. (2011). Paneer production- A review. J Food Sci. Tech. 48(6): 645-660.

Manual in Dairy Chemistry. (1972). ICAR Sub-committee on Dairy Education NDRI Karnal. 31: 84-96.

Nikzade, V., Mazaheri Tehrani, M. and Saadatmand-Tarzjan, M., (2012). Optimiza- tion of low-cholesterol-low-fat mayonnaise formulation: effect of using soy milk and some stabilizer by a mixture design approach. Food Hydrocoll. 28: 344-352.

Olendzki, B.C., Silverstein, T.D., Persuitte, G.M., Ma, Y., Baldwin, K.R. and Cave, D. (2014). An anti-inflammatory diet as treatment for inflammatory bowel disease: a case series report. Nutr J. 13: 5. doi: 10.1186/1475-2891-13-5.

Onning, G., Akesson, B., Oste R and Lundquist I. (1998). Effects of consumption of Oat milk, soya milk, or cow's milk on plasma lipids and antioxidative capacity in healthy subjects. Ann. Nutr. Metab. 42(4): 211-220.

Seuss-Baum, I., (2007). Nutritional evaluation of egg compounds. In: Huopalati, R., López-Fandiño, R., Anton, M., Schade, R. (Eds.), Bioactive Egg Compounds. Springer-Verlag, Berlin Heidelberg. pp. 117-144.

Shahzeidi, M., Nadjarzadeh, A., Rahmanian, M., Salehi Abarghuoei, A., Fallahzadeh, H. and Mogibian, M. (2019). The Effect of Oat Bran Supplement on Fasting Blood Sugar and Glycosylated Hemoglobin in Patients with Gestational Diabetes Mellitus: Single-blind Randomized Clinical Trial. Journal of Nutrition and Food Security (JNFS). 4(1): 7-16.

Srilakshmi, B. (2007). Food Science, $4^{\text {th }}$ Ed. New Age International (P) Ltd., New Delhi. 170-174. 